\title{
From fade-out into spotlight: An audio-visual character analysis (ACIS) on the diversity of media representation and production culture
}

\author{
Christine Linke*, Hochschule Wismar, University of Applied Sciences: Business, Technology \\ and Design, Faculty of Design, Germany \\ Elizabeth Prommer, University of Rostock, Institute for Media Research, Germany \\ ${ }^{*}$ Corresponding author: christine.linke@hs-wismar.de
}

\begin{abstract}
The article focuses on gender portrayal in audio-visual media and discusses the visibility and participation of diverse people. Based on a theoretical framework from gender media studies, we conceptualize audio-visual visibility as a dimension of intersectionality and apply this in an empirical approach. Audio-visual character analysis (ACIS) is introduced as a method to investigate media content in order to describe visibility of the represented people. Applying this method, a quantitative content analysis of a representative sample of German television from 2016 was realized to answer the research questions on the portrayal of relevant characters and on the positions behind the camera. The findings show an unequal representation of gender and an intersectional relevance of other categories of difference such as age as well as an interplay between gender of creative positions and visibility of female characters. The article discusses findings and implications for future research.
\end{abstract}

\section{Keywords}

audio-visual character analysis (ACIS), diversity, intersectionality, gender equality, media production culture, media representation

\section{Introduction and state of research}

Diversity and the media is a vivid issue around the globe. Hereby the matter of visibility on screen, regarding the representation of different people, as well as the participation behind the screen, regarding the diversity of media production, is of relevance. Just recently, activist voices and movements, like Time's Up, 5050X2020, Inclusion Rider and \#OscarSoWhite have contributed to a critical debate on unequal production culture. In Germany, especially the organization Pro Quote Film is addressing the issue. For example, the fact that in spite of an equal gender proportion of directing students at German film schools, only one fifth of television is directed by females (Prommer \& Schoeller Bouju, 2020).

Screen industry has dealt with the challenge of digital change and is nowadays not only producing traditionally film and television. It turned into a convergent and highly digitalized media production sector with strong overlapping to social media content and online distribution.

In light of an established convergence culture (Jenkins, 2006; Jenkins \& Deuze, 2008) including digitalization of production and distribution, audio-visual media is always digital audio-visual media and a vivid part of media culture in the digital age (Storsul \& Fagerjord, 2010). There is no "non-digital" media anymore. We see digital convergence on the production side, the distribution side and the audience side. Audiences can watch a digitally produced movie in a movie theater, but also stream it via platforms. Even though we are aware that analog technologies are still present, usage, storage and distribution of audio-visual media are by now mainly digital. Although audience statistics show the relevance of the digital streaming platforms for the younger audience (Frees, Kupferschmitt, \& Müller, 2019, p. 317), there are no publicly available figures 
from the well-known streaming providers such as Netflix or Amazon Prime on what specific content is used on the respective platforms, how often and for how long. But sporadic publications from market research are available, which show that series produced for linear television, such as Modern Family or Game of Thrones, actually have the most viewers on Netflix \& Co. Originally produced content for the streaming platforms is accordingly less frequently accessed. In its list of the ten most frequently streamed series in December 2019, the German market research company Goldmedia lists eight series that were first broadcast on linear television. For example, the most frequently viewed series in 2019 was Big Bang Theory (Birkel, Kerkau, Reichert, \& Scholl, 2020). Seen in this light, research on visibility in the digital age has to include audio-visual media and hereby the oftentimes seen as traditional, but highly digitalized television media.

Regarding the situation behind the screen, research shows a complex but not complicated picture of gender inequality (Loist \& Verhoeven, 2019). Since the digitalization of the film and television sector, a paradox can be observed, as the digital media industry gives access to production to a much wider range of people while at the same time reproducing old and new forms of hierarchies and inequalities. In her case study, Vicky Mayer (2011) shows the hidden issues of gender, ethnicity and class as well as location and place and formulates a critique of the new media economy. Feminist production studies analyze mechanisms of inclusion and exclusion and put a spotlight on hidden (female) labor in media production within the industry (Banks, 2009). Media industry, together with a number of creative industries, reveals gendered patterns of disadvantage that are increased by requirements for flexibility in media organizations (Conor, Gill, \& Taylor, 2015). Women in particular are in a difficult position dealing with new requirements of self-presentation on the one hand and old patterns such as social and familial responsibilities on the other.
When it comes to diversity on screen, especially gender representations on television draw on a long research tradition worldwide (e.g., Küchenhoff \& Boßmann, 1975; Sink \& Mastro, 2017). However, the question whether the recent changes in the audio-visual media industry have contributed to a more equal situation regarding visibility and participation of diverse people is not answered profoundly. In the US, the actress and producer Geena Davis has been a pioneer on addressing not only the imbalance of gender in the media. She has also been advocating the issue of a connection between role models on screen and societal change. The motto "if she can see it, she can be it" stands for this interrelation and the need to call for it is underpinned by the research of Smith, Choueiti and Stern (2012) showing that female characters are underrepresented in US television. In primetime, there is an average of 39 percent female leading characters. In children and family programs only one-third of the leads are female. Aside from this general underrepresentation, female characters were also seldomly depicted in professional leadership positions. A more recent study also shows an imbalance of gender depiction for primetime television and contradicts the popular theses of a "golden age for female television" (Sink \& Mastro, 2017).

For German television, the last representative study of gender representation was published in the early 2000s. Küchenhoff and Boßmann found in 1975 that women were severely underrepresented, and only a small percentage were given serious plotlines or took part in conversations of social relevance. Their summary of the research: "Men act, women occur" (Küchenhoff \& Boßmann, p. 142). Fifteen years later, Weiderer's (1995) research presented a wider image of women on television, but highlighted that women are usually shown in a lower-level professional position and were still underrepresented. Even in 1990, the year of the study, women were less frequently shown, were stereotypically young, slim and immaculately beautiful. Women of advanced age were hardly ever encountered. In contrast to 
Küchenhoff and Boßmann (1975), women were now seen more frequently in news and topics presented by women were less marginal, but the speaking time of females in information programs made up less than half of those of males. Weiderer measured news time for women of 193 seconds and 499 seconds for men (Weiderer, 1995). In conclusion, Weiderer stated that in 1990 women still were shown in the lower order of priority. The last comprehensive analysis by Lukesch (2004) was conducted in 2002: A sample of about 440 hours of public and commercial television showed once again that females are less likely to occur than males - with a ratio of 35 to 65 percent. At that time, too, the authors found that television was not a mirror image of society, but that women here again were represented as young and beautiful. Looking at specific genres like fictional television series, previous studies (Externbrink, 1992; Scheer, 2001; Weiderer, 1995; Wenger, 2000) showed that the representation of women in series of the 1990s is mainly focused on partnership and family.

What is striking is that there is no more recent representative study for gender images on television in Germany. The question about the visibility of women and men is not part of the regular program research of the television stations. In annual program analysis, which are published for example in the media research journal Media Perspektiven (Krüger, ZapfSchramm, \& Jung, 2018), there is no specific gender breakdown. An analysis according to function and age does not occur.

Current studies that deal with diversity and depiction on screen focus on specific genres (Lünenborg, Linke, Konrad, Fritsche, \& Flecke, 2012; Wolf, 2008). For both German and international children's television, for example, the overrepresentation of male (hero) roles has been confirmed (Prommer \& Linke, 2019; Prommer, Linke, \& Stüwe, 2017). Comprehensive and representative data on the situation for German-speaking television was not available when we started the empirical research in 2016. Therefore, our project aimed at realizing a theoretical founded empirical study that analyzes the visibility of diverse people with emphasis on gender representation. We define visibility as the audio-visual representation on screen and look furthermore into the interrelations between visibility and socio-structural inclusion in media production.

\section{Theoretical background and conceptual framework}

It is not a single program or movie that enfolds an overpowering effect on an audience or on an individual person. Over decades cultural studies have elaborated on the subject and have shown that it is much more the everyday cultural interaction through and with media that is shaping our shared meanings in representations (Hall, 2013). How people are portrayed and how their gender is represented in the media creates ideas of the life world and of identities, which have an impact on the identity construction of the recipients (Klaus, 2005). However, it is important to acknowledge that this media picture is not a mirror of society, but it rather actively produces and reproduces role models and representations of people as well as identities that are based in the structure of an existing media production industry. There is thus a tendency to reproduce and cement traditional gender representations. Laura Mulvey (1985) argues that the representation of females via the male gaze represented in patriarchal Hollywood cinema is threefold: A male director as instructor, a male camera perspective through the cinematographer and a male viewer respectively male audience the film is made for. Still, studies find evidence that this cinematographic apparatus is in place and is creating audio-visual ideas of women and femininity that become part of the societal construction of reality (Lünenborg \& Maier, 2013).

Klaus (2005) has systematized feminist media research into three basic categories: equality approach, difference approach and the (de-)constructivist perspective. She argues that all three perspectives must be integrated into a feminist perspective. Our perspective on the visibility/invisi- 
bility of diverse people and gender in digital audio-visual media takes all three approaches into account. On the one hand, we define quantifiable categories and will measure the visibility with the normative goal of equal representation. On the other hand, we acknowledge that industry structures and journalistic routines influence audio-visual visibility. In order to grasp these interrelations, we correlate the visibility data with data regarding content creators' gender differences. Lastly, from a deconstructivist perspective we interpret our findings in the context of existing power structures in society and media industries and try to uncover the 'doing gender' in digital audio-visual media.

Regarding the analysis on visibility in audio-visual media and the theoretical framework the following research questions are addressed:

1. How diverse with regard to gender and age are relevant characters on German TV-screens?

2. How are relevant characters portrayed in television?

3. How diverse are the positions behind the camera casted? And, does this have an influence on the visibility of diverse people?

To analyze these questions, we use the perspective of deconstructionist, anti-identitarian gender theory (Butler, 1990, 2009) as well as intersectionality theory (Crenshaw, 1989). Winker and Degele (2011) have shown that issues of equality and anti-discrimination should not just be based on single-issue categories such as gender. At the same time, we acknowledge that statistics are employed in evidence-based argumentation to affect political strategies and change legal frames. We therefore combine the intersectional theory with communication theory addressing media representation and methodological work especially on media content analysis. This empirical approach is based on the definition of distinct categories and the proverbial counting of manifestations on visibility in the media text. However, such pragmatic, clear categories seem to be at odds with deconstructionist theories, which are set up to problematize clear-cut identities and categories. We are aware of this aspect and aim to problematize normalizing action. At the same time we value the anti-normative potential of quantitative analysis in order to bring invisibilities into spotlight (Brown, 2010). Therefore, we conceptualize audio-visual visibility as a dimension of intersectionality and apply this dimension in a quantitative empirical approach. This perspective is based on an understanding of societal roles as for the most part not firmly established, but rather shaped fluidly through engagement with the social environment (Butler, 1990). Gender is understood as a social category, and this perspective is interwoven with an observation of people's social behavior, their "doing gender" (Fraser, 2007; West \& Zimmerman, 1987). As media has an important cultural impact, it is also the "doing in / on media" that is of interest. Research on gender and media has a long history and especially questions of representation, production and consumption can be highlighted (Krijnen \& van Bauwel, 2015). Over and above gender as one of the most discussed and social relevant categories of difference, a perspective on the diversity of media representation enables an integrative perspective for media studies (Linke, 2016). In order to focus on the visibility of diversity on German television and to answer the research questions above, we will in the following describe our methodical approach to identify visibility of human representation and to interpret this visibility as a dimension of intersectionality.

\section{Method and procedure}

In order to answer the research questions a study design was developed with the following propositions: The study should include comprehensive material of German television. The data should be comparable and enable representative statements on the research questions regarding gender, age, and a visible function of the persons (like news anchor or politician) and provide information about a possible causal- 
ity between diversity in front and employment behind the camera. Aiming at an overall picture for Germany, we decided to include the major television broadcast and cable stations to gather representative data (for more information, see Prommer \& Linke, 2019, pp. 33-47). The method of choice was a quantitative content analysis that allows for a systematic, structured and comparative analysis of larger amounts of material (Krippendorf, 2018). It is used in communication and media studies to identify a measurable portrayal of topics or characteristics in different media.

Our specific aim was to find a robust and comprehensive approach to identify visibility of human representation and to interpret this visibility as a dimension of intersectionality in nowadays mediated life worlds. We therefore designed a methodical approach we refer to as audio-visual character analysis (ACIS) that enables to investigate how often and in which roles people appear in fictional productions, entertainment and information programs. ACIS enables to point out certain differences in the material. This is necessary because television contents are differently structured. There are also differences within television between television genres, for example between news programs in the information area or quiz shows in the area of non-fictional entertainment. The analysis of the television programs distinguishes quite classically the three program sections fiction, non-fictional entertainment and information. Fictional programs are series and television films with fictional actions and stories. The non-fictional entertainment refers to formats that reflect real facts, settings and situations but with a primarily entertaining character, for example quiz or music shows. Information includes journalistic genres, such as news broadcasts, talk show formats and documentaries, as is best described by its characteristic of news values. Each of the three program sections can be differentiated further into different formats (Weiß, Beier, \& Wagner, 2015).

ACIS combines elements of standardized quantitative content analysis with narrative and reception-aesthetic film analysis (Eder, 2013; Mikos, 2008). For each program section, the relevant characters were measured. Since different program divisions were examined, different definitions of what the main characters and protagonists are, were used. There is a lively debate in film studies on how to define the fictional protagonists and how to record them analytically (e.g., Mikos, 2008, pp. 163-170), which ultimately leads to a wide variety of definitions. Thus, a robust definition that is applicable to all formats had to be found for empirical implementation. These definitions were subjected to multiple inter- and intra-coder-reliability tests and proved to be valid, reliable and stable for the respective program sections and genres (ø ICR: .89 for the ACIS core variables ranging from .80 to .98 ).

For the fictional programs, we use the term protagonists in accordance with the figure theory of the film scholar Jens Eder. Protagonists are the figures who take on a leading role and pursue central narrative goals (Eder, 2013). A "protagonist" is the character who is the driving force behind the story and who acts in a goal-oriented manner. Furthermore, protagonists in television series were distinguished above all by their enduring character, i.e. they were part of the series' permanent ensemble. The combination of narration and ensemble related criteria helps to identify relevant figures in audio-visual media.

For television content without scripts and plots (like news or entertainment shows) it was important to determine the visibility of people by other criteria. For this purpose, we inductively developed a robust definition from the work with the specific programs. In non-fictional television broadcasts people are both visually (frequency, density and focusing) and audibly (voice, intercom) perceptible. In information/journalistic formats and in non-fiction entertainment formats, the analysis focused on the main characters. In information formats (e.g., German news broadcast "Tagesschau"), three criteria had to be met: A name was mentioned (e.g., is written and/or clearly 
Table 1: ACIS coding of the relevant characters

\begin{tabular}{|c|c|c|}
\hline Fictional program & Information program & Non-fictional entertainment \\
\hline $\begin{array}{l}\text { protagonist = the character } \\
\text { who is the driving force } \\
\text { behind the story and who } \\
\text { acts in a goal-oriented } \\
\text { manner }\end{array}$ & $\begin{array}{l}\text { main character = each person who is } \\
\text { centrally visible and has their name } \\
\text { mentioned and speaks (e.g., TV host, } \\
\text { news anchor, journalist, reporter, } \\
\text { politician, expert, guest) }\end{array}$ & $\begin{array}{l}\text { main character=the person leading } \\
\text { through the program (e. g., quiz } \\
\text { master, but not the guests; show host, } \\
\text { but not candidates) }\end{array}$ \\
\hline
\end{tabular}

stated twice), the person was audible (e.g., moderation or original sound) and visibly central to the image section shown. Main criterion in the non-fictional formats was whether the person was in a leading position and became the main character of the program (Table 1).

The ACIS takes up the perspective of the audience, thus excluding editorial and professional contextual knowledge or background knowledge. Instead, only what becomes visible and audible in the broadcast flows into the coding.

First, the appearing persons on TV and their roles (here: protagonist, main character) were identified in the coding process. Then the characters were examined in more detail by analyzing individual characteristics such as gender, age, sexual orientation and specific characteristics that can be clearly coded (e.g., body shape, relationship status, parenthood, profession). The gender of the characters was basically coded non-binary, i.e. openly. Apart from a binary understanding of gender (females and males), all potentially possible categories such as inter- or transsexual or neutral could be coded (referred to here as "other gender"). The same procedure was applied to sexual orientation, with all other possible variants being recorded in addition to hetero-, homo- or bisexual.

By using the ACIS and thus taking the perspective of the audience without prior knowledge, the characters relevant for the analysis had to be explicitly addressed with a gender (female, male or other gender) or made recognizable by themselves. The procedure also applied to sexual orientation. In this context, it must be mentioned that sexual orientation, if it was not explicitly mentioned, was to be coded as "not recognizable". This led to a high number, over half of the appearing characters with not recognizable sexual orientation, since this applies to almost all persons in news and information programs. In addition to the gender, other factors such as age and thematic context were examined. The category system was checked for validity and reliability in several stages. Coding was realized by six coders who were trained extensively and were guided through the process. Test coding in the pre-evaluation phase led to a reworking of the code surveys to allow a precise adjustment of the examination instrument to the object of study. Selected examples also supported this process. The inter- and intra-coder agreement in several stages ensures that the coding is valid and unambiguous (ø ICR: 0.86 ranging from 0.80 to 0.98 ).

The study is based on a quantitative content analysis of a representative sample of German television from 2016 (over 3500 hours, 21 TV programs). This data provides a comprehensive picture of the current situation on German screens. To capture this representative sample, a 14 days sample of two artificial weeks (random sample) composite of television programming (2 to 12 p.m.) across 17 major public service and commercial broadcast networks was constructed. This random sample is representative for 85 percent of the German television market.

The sample was analyzed with the ACIS-based coding system. The first step defined a single program as the unit of analysis. All programs were coded regarding the visible characters and their characteristics. Furthermore, other categories for the program and the genre of media were coded according to an own adaption of an established program scheme of German television (Weiß et al., 2015). In total for 
regular TV 2945 programs were analyzed with ACIS adding up to 11144 protagonists and main characters.

Moreover, the gender of the people behind the camera was coded. In the following, we present the data for the five creative positions that were examined for each fictional TV program. It was coded whether a man, a woman, a women's team, a men's team or a mixed-gender team was responsible for the direction, the screenplay, the production, the camera department and as commissioning editor(s).

\section{Findings}

We have organized our findings along the research questions addressed: (1) How diverse with regard to gender and age are relevant characters on German TV-screens? (2) How are relevant characters portrayed in television? (3) How diverse are the positions behind the camera casted? And, does this have an influence on the visibility of diverse people? The last question leads to an interrelation between the gender of the content creator and the visibility of female characters.

The following figures are all based on statistically relevant and significant results. They are representative for the German television of the year 2016 .

\subsection{Research question 1: How diverse with regard to gender and age are relevant characters on German TV-screens?}

\subsubsection{Key finding 1: Unequal representation and age gap}

The first findings of the study show that a binary visibility of gender is manifested in German film and television. Non-binary gender representations are almost non-visible ( $\mathrm{n}=9$ of 11144 main protagonists). Thus, the data show that transgender and other gender identifications are not represented in German television. This is evidence for a non-diverse representation in German media industry that must be profoundly problematized and reflected. Against the background of this situation, the following analysis focuses on the underrepresentation of females.

Regarding the representation of female and male main characters in journalistic content (information) and protagonists in fictional and non-fictional entertainment, for German television the study shows an overall underrepresentation of female relevant characters. Across all television programs and genres there are two men for every woman (Figure 1). One third of the programs do not have any female relevant characters at all (compared to only $15 \%$ female only programs). Only telenovelas

Figure 1: Gender representations of relevant characters in German TV programs ( $n=11$ 144)
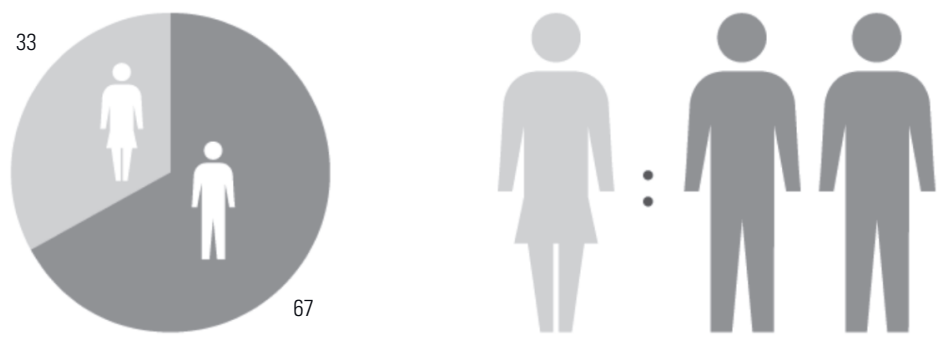

Note: Female $n=3,659(33 \%)$, male $n=7485(67 \%)$. 
Figure 2: Gender distribution of main characters and protagonists by television genre (German productions or co-productions) (in percent)

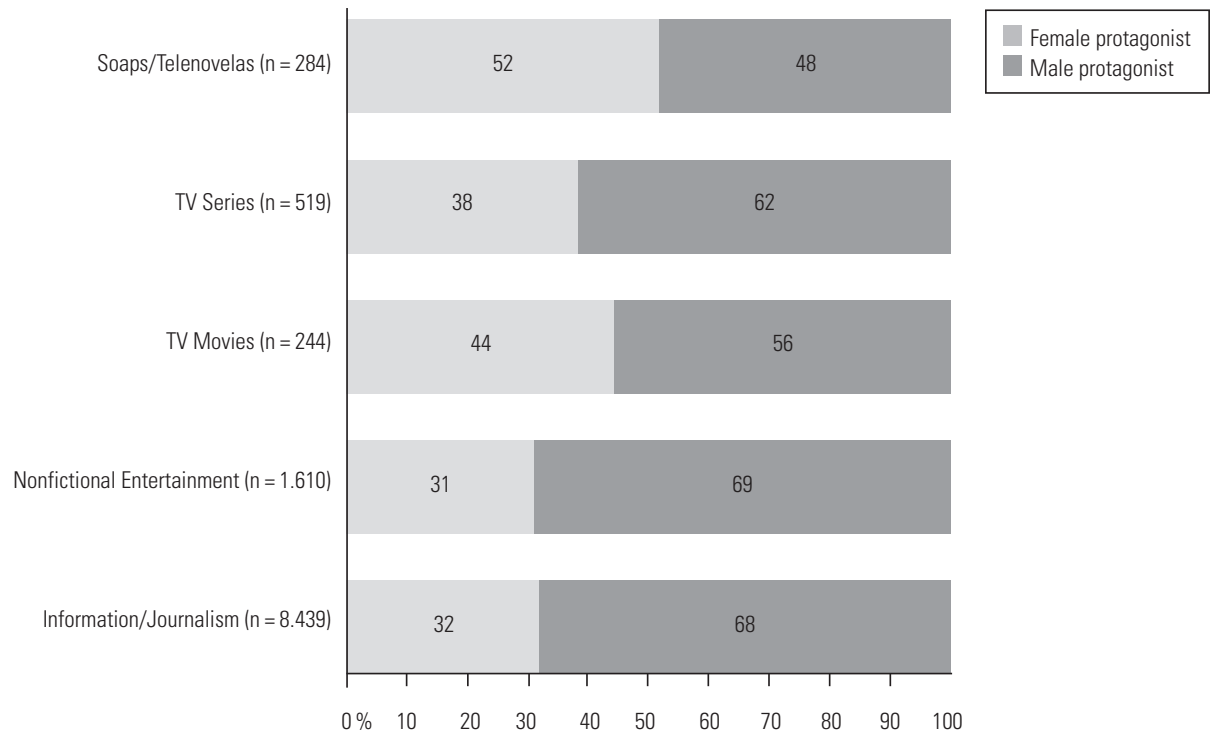

Figure 3: Age-gap in German television, $\mathrm{n}=10663$

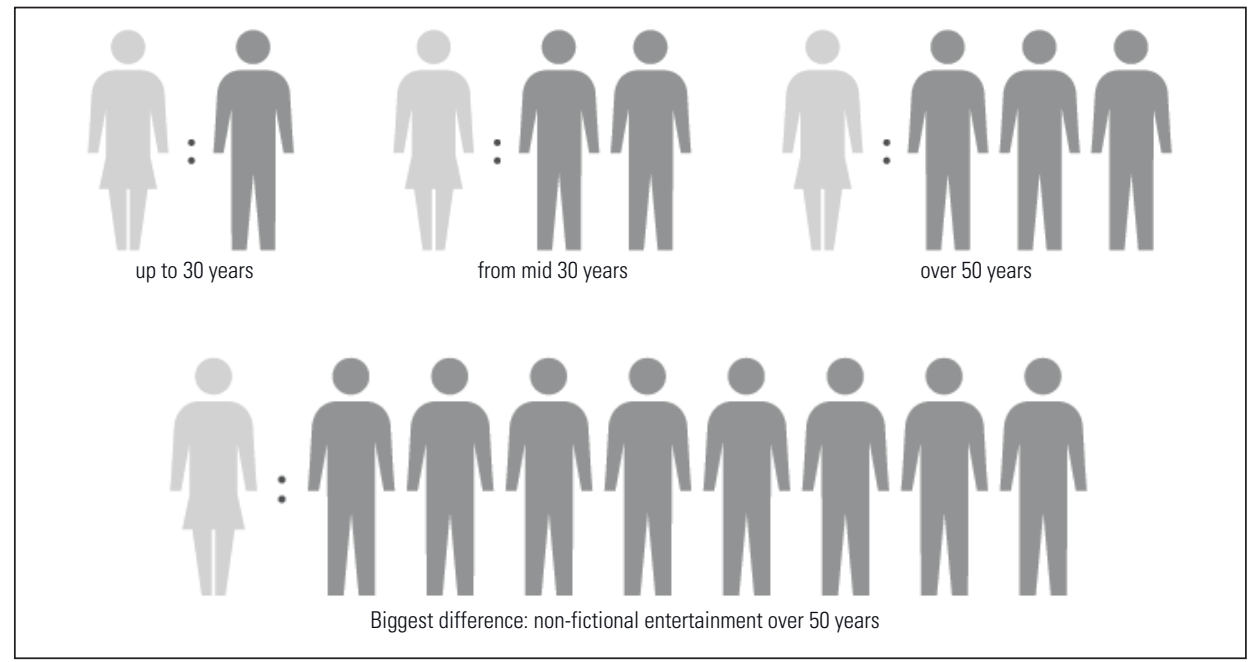

and daily soaps are representative of the actual gender distribution in Germany, i.e. about $51 \%$ women and $49 \%$ men. However, these formats only account for $3 \%$ of all programs. This finding concerns all TV stations, public and private, and nearly all genres (Figure 2).

If women appear, they appear as young women (Figure 3). From the age of 30 onwards, women gradually disappear from the screen. This applies to all stations and 
Figure 4: Journalistic functions in information programs by gender (in percent)

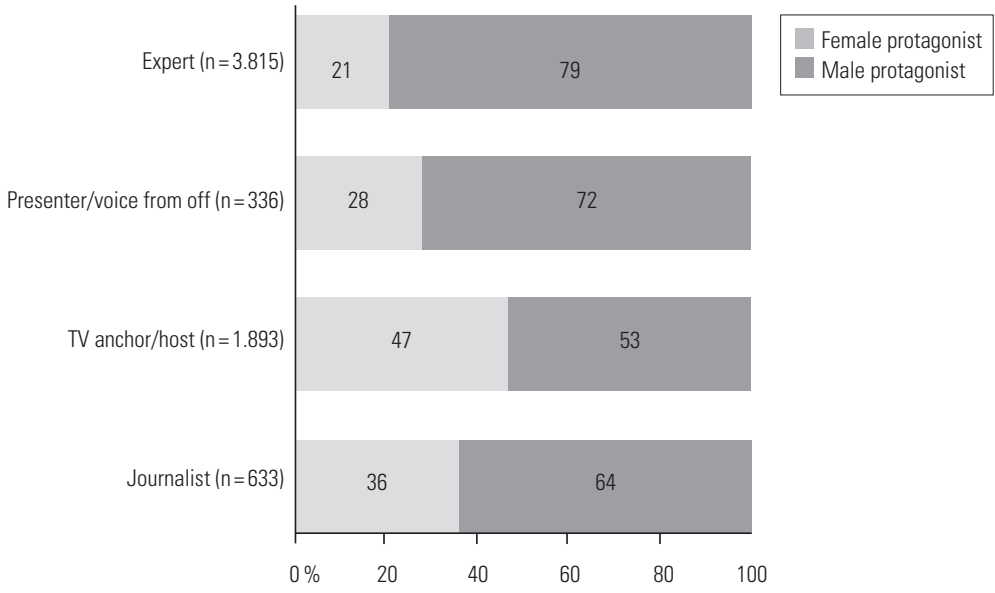

across all formats and genres. Up to the age of 30, women appear more often (in fictional and non-fictional entertainment formats) or about as often as men. From the mid-30s on, the constellation changes: In this age-group there are two men for every woman. From 50 years of age on there are three men for every woman. The biggest difference we find in non-fictional entertainment: Over 40 there are four men for every woman, over 50 there are eight men for every woman.

\subsection{Research question 2: How are relevant characters portrayed in television?}

\subsubsection{Key finding 2: On TV, men explain the world, women are faded out}

Since women are overall underrepresented in all TV genres but telenovelas, we wanted to see if there are journalistic functions, such as television anchor or expert, where women might be more or less visible. The only function, where we see an almost gender balance, is the TV news anchor. In all other functions (e.g., voice from the off, visible journalist, expert) females are underrepresented. Regarding the function, the portrayed persons filled in fictional as well as in information genre, the data show an imbalance especially regarding the gender of experts. Eight out of ten ex- pert functions are occupied by men, both in information and entertainment shows. Figure 4 documents the situation for the information program section in detail.

In order to understand this lack of female experts, we decided to include external data to investigate this issue more closely. One explanation would be that there might be fewer women available as experts because hardly any women work in these professions and subject areas. An argument that we often heard in discussions with journalists and media decision makers: "What are we going to do: The mayor or foreign minister is male?"

Aiming to determine whether there are enough women available as experts, we used data from the German Federal Statistical Office on the gender distribution in the various professions and researched the respective professional associations, such as the German Medical Association, the Bar Associations, and the German Association of Lawyers. It shows that even in those professional fields in which women are overrepresented in reality, they remain comparatively underrepresented on television. Thus, television shows an outdated picture of living environments and a distorted picture of our social reality. 
Figure 5: Women experts and their professional fields: Comparison of relevant characters in information television programs and real life in the professional field (in percent)

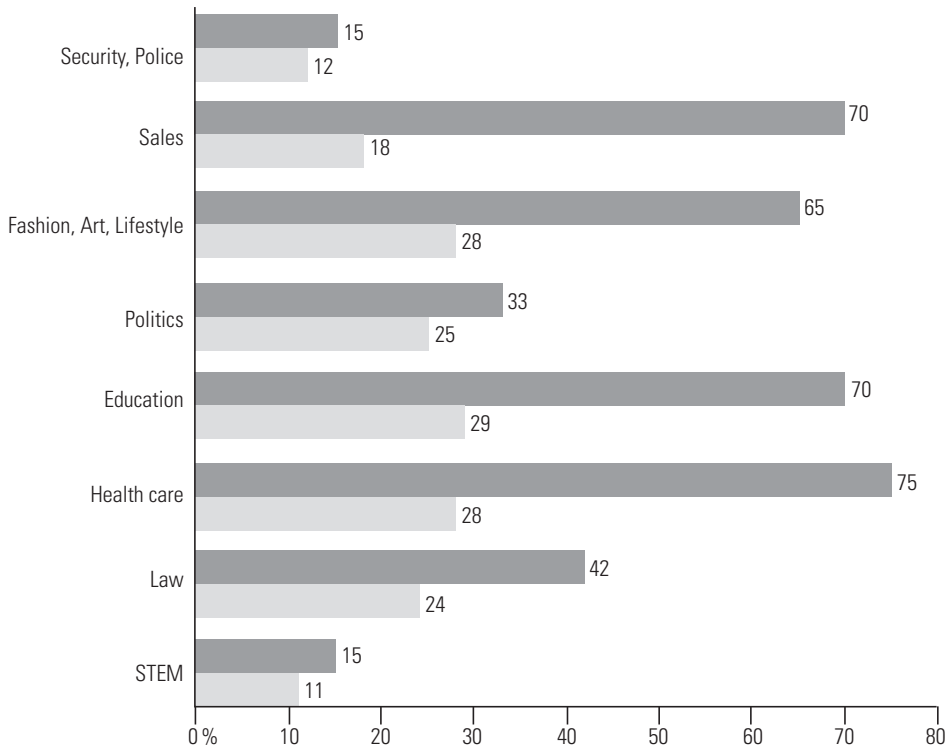

In detail: In real life, half of the judges as well as the prosecutors in the German legal system are female prosecutors (Bundesjustiz, 2017). However, since more men than women work as independent lawyers, we have averaged the sums proportionately and arrived at a gender distribution in the professional field of "law" of $42 \%$ women and correspondingly $58 \%$ men. Looking at the number of female experts in the field of "law" in the information programs, women appear almost half as often as in real life $(24 \%$, see Figure 5). The situation is similar in the area of "health and care". The German Medical Association (Bundesärztekammer, 2017) reports that in 2016 half of all doctors were female. Medicine is a field in which women are so powerful and strong that even some male university professors are demanding a male quota for admission to university (Pospiech, 2018). There is, however, a drastic under-representation on TV. In the field of "health and care" we see women less often than in real life. If we weight the different occupational groups, three-quarters of the people working in the health and care sector are female. This proportion is different for female experts on screen. On German television, women are represented by only $28 \%$. In other words: They are under-represented by $300 \%$, i. e. they are almost three times less common than in reality.

The same picture emerges in the area of "education". A look at the schools shows: In the classrooms female teachers predominate, often women run the schools and there are many more female kindergarten teachers than male (Destatis, 2020). Overall, women are very active in the area of "education" accounting for $70 \%$ of the total (Destatis, 2020). As TV experts they are again underrepresented: Only $29 \%$ are women, $71 \%$ are men. In other words, men are more than twice as likely to appear on television in this professional field as in real life. This disproportionate number of men is present in all areas, whether in the financial sector, the service sector or in sales professions.

There are a few exceptions: In the field of "politics and administration" women are almost as common as in real life. We see $25 \%$ women as experts on television, whereas in 2017, in fact, about $33 \%$ 
of those working in politics were female (Bundestag, 2020). Although fewer women politicians appear on television than in real life, the difference is not as marked as in other areas. In the professional fields of "security and police" as well as in the STEM (in German "MINT") professions, women are also shown roughly in line with reality.

We have also examined television series, soap operas and television films according to the same logic. There, too, we have assigned all protagonists, if possible, to the professional fields in which they work (total protagonists with identifiable professions $n=976$, female $n=298$, male $\mathrm{n}=678$ ). It should be mentioned here that authors have the freedom to write more female politicians or chief physicians in their scripts. At the same time, it must be stressed here that fiction per se does not have to reflect reality.

The picture also lags frighteningly behind reality. Even in fiction, women appear less frequently in the professional fields than in real life. On German TV screens, there are half as many women bankers, lawyers, doctors and nurses, fewer female administrative staff, teachers and educators than in real life. The only exceptions are the many female commissioners of crime series. In the field of "security", female protagonists are more strongly represented in fictional programs than in real life, at $28 \%$ they appear almost twice as often (15\%, Destatis, 2020).

Otherwise, however, women are less frequently found in the imagined stories of television in all areas of life than in real life. Even as schoolgirls and students they are underrepresented. In reality, half of the student body is made up of female students - just as in the case of college and university students (Destatis, 2020). But on television only $38 \%$ are female.

Therefore, we can argue for German television: Overall, women occur less frequently, they do rarely appear as experts, even in professional fields such as education, in which they are well represented and would be available as experts.

\subsection{Research question 3: How diverse are the positions behind the camera casted? And, does this have an influence on the visibility of diverse people?}

\subsubsection{Key finding 3: Interplay between gender of creative positions and visibility of women}

Further findings show the intersection of visibility on screen and participation behind the screen. The question arises how the images we see on television are created: Who are the responsible media makers? What does this mean for the visibility of women and men on the screens? Is there a mechanism of fading out or how can the unequal representation of the sexes be explained? Does it matter whether a woman wrote the screenplay or a man? Does the gender of creative above-the-line functions have an influence on the visibility of the sexes? In addition to the visibility of women and men on screen, we also examined the creative leadership functions involved in the television production.

Analyzing the gender distribution of the creative functions behind the camera shows a significant under-representation of women for German television in 2016. One cannot speak of diversity behind the camera. The basis of the analysis are those of the 310 German produced fictional television programs where we could identify the director $(n=283)$, director of photography $(n=270)$, producer $(n=280)$, writer $(n=271)$ or commissioning editor $(n=182)$, either via the credits or via online desk research. We excluded co-production here since there are different decision processes for international co-productions. In contrast to the above calculation, the analytic basis are not the protagonists or actors, but the individual programs.

Women directed slightly more than one in ten fictional programs (12\%). In eight percent of the cases women were part of a mixed team, which is more common in soap operas. This means that in 80 percent of the cases no woman was involved in directing. Seen in this light, almost two thirds of the scripts were written only by 
Figure 6: Gender distribution of creative functions in fictional television programs produced in Germany in 2016, based on programs from all broadcasters (in percent)

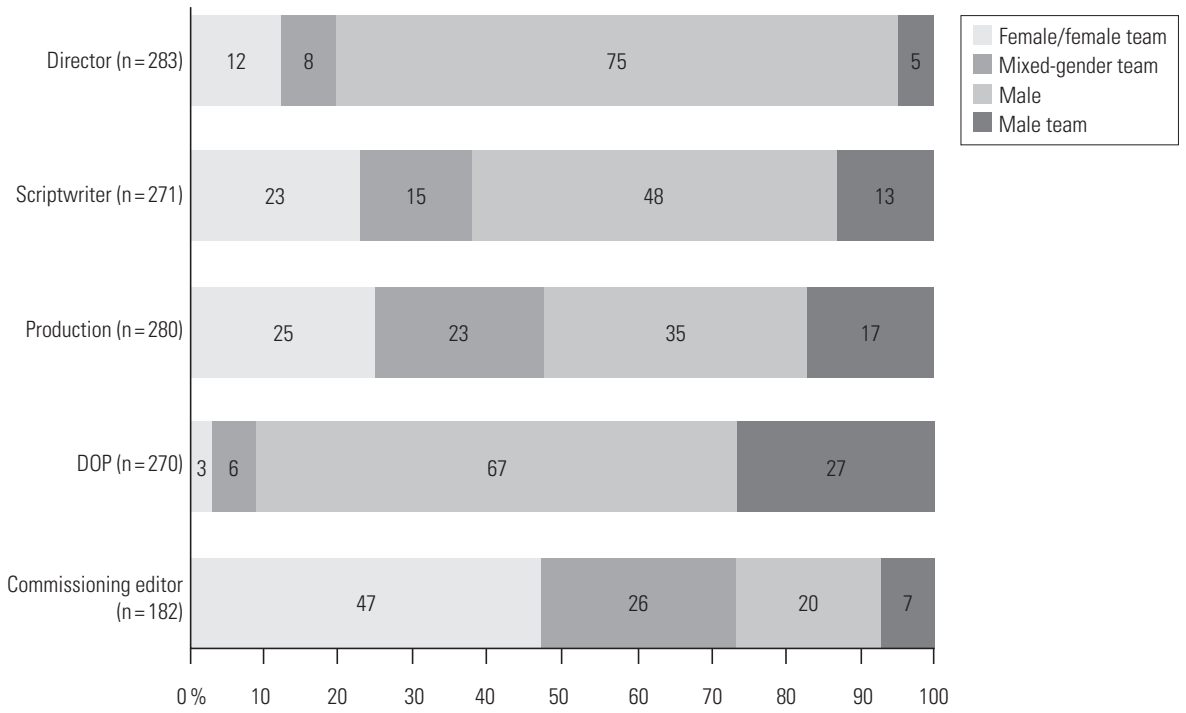

Note: Deviations from $100 \%$ are due to rounding error. The figure shows only those cases for each position where the persons filling them could be determined. Due to the low share of female teams in almost every creative function, these were added to the category female. Director female team $n=1(0.4 \%)$; script female team $n=12(4 \%)$; producer $n=11(4 \%)$. Only in the category commissioning editor there are 25 female only teams (14\%).

Figure 7: Average of female protagonists and the intersection of the gender of the creative team for fictional television programs produced in Germany in 2016 TV programs

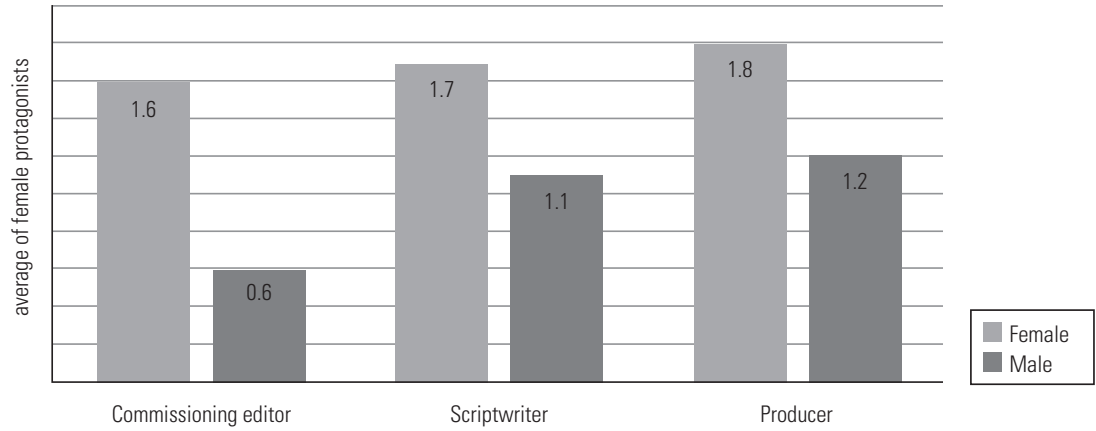

Note: T-test results for commissioning editor: male $(M=0.6 ; S D=0.9 ; n=36)$, female $(M=1.6 ; S D=1.3 ; n=62), t(96)=3.8$, $p<.001$; scriptwriter: male $(M=1.1 ; S D=0.9, n=130)$, female $(M=1.7 ; S D=1.5, n=51), t(179)=3.5, p<.001$; Producer: male $(M=1.2 ; S D=0.9, \mathrm{n}=90)$, female $(M=1.8 ; S D=1.7, \mathrm{n}=53), t(141)=2.7, p<.01$.

Basis: All fictional German productions, where the persons filling the positions could be determined. The comparison is only made for those cases where the position was filled by a single woman or a single man. Too few cases for director and DOP to conduct t-test and compare averages. 
men $(61 \%)$, and almost no women were involved in the camera department $(3 \%$ female and $6 \%$ mixed gender teams). The ratio is more balanced for the position of the producer, where women are involved in almost half of the films (48\%), and women are even prevalent in the television commissioning editorial departments. In almost three quarters of the projects, women are involved as commissioning editors $(73 \%)$ and men in only $53 \%$. Due to the mixed gender teams $(26 \%)$ there is an overlap here (Figure 6).

The results show that the television and film industries are areas with highly asymmetric access to creative positions in production. Females are significantly less represented than males. If we look at German fictional television, i. e. television series, television films and soap operas, it becomes clear that a single female commissioning editor in charge makes almost three times as many women visible as a man. With a female commissioning editor, we see an average of 1.6 female protagonists, with a male editor only 0.6 (Figure 7). If a woman writes the script or produces a program, we also see considerably more women on the screen. Since there are so few female directors and female directors of photography (DOP), the numbers are too small and therefore the results are not significant.

The gender of the commissioning editor, scriptwriter and producer in television is significantly related to the visibility of leading female characters on screen. In summary, the data show that the more women are in leading positions behind the camera, the more women we see on the screen as protagonists. This in turn means that both the person(s) who work(s) behind the camera and the gender distribution are important regarding the visibility of women on screen.

\section{Discussion and conclusion: Audio-visual intersections from fade-out into spotlight}

This research has brought up three key findings that bring audio-visual intersec- tions of unequal representation into spotlight. Firstly, German television is a space of unequal representation of gender including an intersectional age gap. Women are underrepresented in German television. Other gender than the overrepresented male, and the faded-out females, are almost completely invisible. Furthermore, the data show an intersection between gender and age, i.e. an age gap. Women on screens are predominantly young. After the age of 30, women appear gradually less on German screens. These findings can be interpreted according to intersectional theory, highlighting a combination of discrimination by the intersectional categories age and gender, in this case for women of age. This intersection of femininity and increasing age is accompanied by a fade-out from audio-visual representation (Douglas, 2020).

Secondly, a closer look on the social roles and contexts of representation depicted in TV formats shows that male characters are dominantly visible in positions of expertise and knowledge: In German television it seems that men explain the world. Women are faded out. Other gender, again, are invisible. Comparing the data with German national statistics and data from professional institutions we see that television representation is undermining the functions women have in real life. Furthermore, the TV age gap reinforces the effect that women are underrepresented as experts. At an age when women could be experts in their professional fields due to many years of experience, they are hardly ever seen on television.

Thirdly, the study shows an interplay between gender of creative positions and visibility of women on the screen. The argument of an intersection between involvement in media production and the diversity of representations is supported.

The findings of the study can be integrated in the picture that the international body of research draws. Empirically analyzing representations and hereby visibilities and invisibilities is a fruitful way for media studies to investigate inequalities. Our proposition to use gender media studies and intersectionality theo- 
ry by applying visibility as a dimension of intersectionality proofed as a reasonable approach. As our analysis exposed a binary and non-diverse picture of representations on German TV screens, the analysis focuses on the matter of underrepresented female characters. For future research and application of the conceptual framework, it is important to broaden both the approach and the database in order to further analyze the diversity of representation as well as the intersectionality of variables of difference.

Nearly 10 years ago, Hegde (2011) published on the Circuits of Visibility and pointed to a "global flow of media technologies, migration and the unfettered mobilities of capital [that] rework old logics of domination in new global forms" (p. 1). These issues are still relevant, if not intensified. Research, which is on the one hand based on the state of the art and is answering theoretical requirements and on the other hand accessible to public debate, legislation and activist movements is crucial. Our intention here was to enable both.

Considering that one of the central decisions was to enable a comprehensible study on German television with a representative sample, the study answers questions on a more general level. Therefore, there are limitations regarding more detailed insights within genres as it is not possible to compare single programs as there is no representative information value on this level. Furthermore, it has to be acknowledged that the findings are based on coded quantifications and are not adequate to analyze more contextualized and complex dimensions of characters, for example regarding stereotypic gender representation. Moreover, we have, for example, coded the gender of the so-called key "creative team" positions according to a definition that is used in Germany, Australia and Sweden to measure gender inequality in the industry (Filmförderungsanstalt [FFA], 2020). This includes the production roles of the producer, screenwriter and director. We acknowledge that other creative positions, such as the director of photography (DOP), editor, sound and costume design- ers are also important creative roles. For the purpose of this research, however, we adhered to the more widely used industry definition of a key creative team. Therefore, the more complex unequal structures discussed in feminist production studies were not analyzed in detail. Nevertheless, the representative findings in this study underline the unequal situation regarding the creative positions in the German audio-visual media industry.

Last but not least, in this study we used a new methodical approach that combines coding steps of classical quantitative content analysis with a more qualitative, but still standardized analysis of visibility of character attributes including dimensions like represented gender, age and sexual orientation as well as specific content and presentation forms. We introduced our ACIS, which allows to code any audio-visual content to describe the visibility and diversity of the people shown on screens. For this purpose, the relevant person is identified by means of film-theoretical concepts such as narration or relevance. In this article, we used the ACIS for TV content. Furthermore, we have been applying the method for cinema movies (Prommer \& Linke, 2019), YouTube (Prommer, Wegener, \& Linke, 2019; Wegener, Prommer, \& Linke, 2020) and streaming media, thereby showing that ACIS can be adopted for any audio-visual medium. ACIS hereby allows a comparability of different audio-visual media measure for visibility: If analyzed using ACIS it is possible to compare different media genres, for example, regarding the visibility of diversity. We were, for example, able to show that German language YouTube is by no means more gender-equal than television, as the female representation for the most popular YouTube channels is less frequent and reduced to traditional topics like beauty and DIY (Prommer, Wegener, \& Linke, 2019; Wegener, Prommer, \& Linke, 2020). Once again, this finding is another argument for the relevance of research into convergent media representations as visibilities in the digital age. 


\section{References}

Banks, M. J. (2009). Gender below-the-line: Defining feminist production studies. In V. Mayer, M. J. Banks \& J. T. Caldwell (Eds.), Production studies: Cultural studies of media industries (pp. 87-98). New York: Routledge.

Birkel, M., Kerkau, F., Reichert, M., \& Scholl, E. (2020). Pay-Video-on-Demand in Deutschland, Markt und Nutzung kostenpflichtiger Streamingdienste [Pay-video-on-demand in Germany: Market and use of paid streaming services]. Media Perspektiven, 1, 22-32.

Brown, K. (2010). Queer quantification or queer(y)ing quantification: Creating lesbian, gay, bisexual or heterosexual citizens through governmental social research. In K. Browne \& C. Nash (Eds.), Queering methods and methodologies: Queer theory and social science methods (pp. 231-249). London: Ashgate.

Butler, J. (2009). Performativity, precarity and sexual politics. AIBR: Revista De Antropología Iberoamericana, 4(3), i-xiii.

Butler, J. (1990). Gender trouble: Feminism and the subversion of identity. Thinking gender. New York: Routledge.

Bundesärztekammer (2017). Berufstätige Ärzte [Working doctors]. Retrieved from https:// www.bundesaerztekammer.de/ueber-uns/ aerztestatistik/aerztestatistik-der-vorjahre/aerztestatistik-2017/berufstaetige-aerzte/.

Bundesjustiz (2017). Richterstatistik 2016 [Statics of judges]. Retrieved from https:// www.bundesjustizamt.de/DE/SharedDocs/Publikationen/Justizstatistik/Richter statistik_2016.pdf.

Bundestag (2020). Abgeordnete [Representatives]. Retrieved from https://www. bundestag.de/abgeordnete/biografien/ mdb_zahlen_19/frauen_maenner-529508.

Conor, B., Gill, R., \& Taylor, S. (2015). Gender and creative labour. The Sociological Review, 63, 1-22. https://doi. org/10.1111/1467-954X.12237.

Crenshaw, K. (1989). Demarginalizing the intersection of race and sex: A black feminist critique of antidiscrimination doctrine, feminist theory and antiracist politics. University of Chicago Legal Forum, 1.
Retrieved from http://chicagounbound. uchicago.edu/uclf/vol1989/iss1/8.

Destatis (2020). Erwerbstätige nach Wirtschaftszweig [Employees by industry]. Retrieved from https:// www-genesis.destatis.de/genesis/online?sequenz=tabelleErgebnis\&selectionname=12211-0009\#abreadcrumb.

Douglas, S. J. (2020). In our prime: How older women are reinventing the road ahead. New York: Norton.

Eder, J. (2013). Die Figur im Film. Grundlagen der Figurenanalyse [The figure in the film: Fundamentals of figure analysis]. Marburg: Schüren Verlag.

Externbrink, A. (1992). Nur eine Mutter weiß allein, was lieben heißt und glücklich sein eine Kritik zur Darstellung der Frau in der Fernsehserie Lindenstraße [Only a mother alone knows what it means to love and to be happy-a critique of the portrayal of the woman in the television series Lindenstraße]. In R. Knigge-Tesche \& H. Tompert (Eds.), Frauenbilder im Fernsehen. Beiträge und Materialien einer Fachtagung vom 25. bis 27. August 1991 in Augsburg [Television pictures of women. Contributions and materials of a conference in Augsburg 1991] (pp. 73-90). Bonn: Bundeszentrale für politische Bildung.

Filmförderungsanstalt (2020). Genderverteilung FFA-Produktionsförderung 2015 bis 2019 [Gender Distribution FFA Production Funding 2015 to 2019]. Berlin.

Fraser, N. (2007). Transnationalizing the public sphere: On the legitimacy and efficacy of public opinion in a post-westphalian world. Theory, Culture \& Society, 24(4), 7-30. https:// doi. org/10.1177/0263276407080090.

Frees, B., Kupferschmitt, T., \& Müller, T. (2019). ARD/ZDF-Massenkommunikation Trends 2019: Non-lineare Mediennutzung nimmt zu. Ergebnisse der repräsentativen Studie im Intermediavergleich [ARD/ZDF-mass communication trends 2019: Non-linear media usage increases. Results of the representative study in an intermediary comparison]. Media Perspektiven, 8, 314-333.

Hall, S. (2013). The work of representation. In S. Hall, E. Evans \& S. Nixon (Eds.), Represen- 
tation: Cultural representations and signifying practices (pp. 13-74). London: Sage. Hegde, R. (2011). Introduction. In R. Hegde (Ed.), Circuits of visibility: Gender and transnational media culture (pp. 1-17). New York, NY: New York University Press.

Jenkins, H. (2006). Convergence culture: Where old and new media collide. New York: New York University Press. Retrieved from http://hdl.handle.net/2027/ heb.05936.0001.001.

Jenkins, H., \& Deuze, M. (2008). Convergence culture. Convergence: The International Journal of Research into New Media Technologies, 14(1), 5-12. https://doi. org/10.1177/1354856507084415.

Klaus, E. (2005). Kommunikationswissenschaftliche Geschlechterforschung. Zur Bedeutung der Frauen in den Massenmedien und im Journalismus [Gender Studies in communication studies: On the significance of women in the mass media and journalism] (updated and corrected new ed.). Wien: Lit.

Krijnen, T., \& van Bauwel, S. (2015). Gender and media: Representing, producing, consuming. Communication and society. London, UK: Routledge.

Krippendorf, K. (2018). Content analysis: An introduction to its methodology ( $4^{\text {th }}$ ed.). London, UK: Sage.

Krüger, U. M., Zapf-Schramm, T., \& Jung, M. (2018). Sendungsformen, Themen und Akteure im Nonfictionangebot von Das Erste, ZDF, RTL und Sat.1. Programmanalyse 2017 (Teil 2) [Program forms, themes, and actors in the non-fiction program of Das Erste, ZDF, RTL and Sat.1: Program analysis 2017 (Part 2)]. Media Perspektiven, $5,242-262$.

Küchenhoff, E., \& Boßmann, W. (Eds.) (1975). Die Darstellung der Frau und die Behandlung von Frauenfragen im Fernsehen [The representation of women and the dealing with women's issues on television]. Stuttgart: Kohlhammer.

Linke, C. (2016). Identity, diversity and difference: An exploration of the transmedia experience of fashion reality TV and social media. In C. Richter, I. Dupuis \& S. Averbeck-Lietz (Eds.), Diversity in transcultural and international communication (pp. 147-166). Wien: Lit.
Loist, S., \& Verhoeven, D. (2019). Complex not complicated: Gendered media industries in the wake of \#MeToo. Media Industries Journal, 6(10), 67-71. https://doi. org/10.3998/mij.15031809.0006.104.

Lukesch, H. (2004). Das Weltbild des Fernsehens [The world view of television]. Regensburg: Roderer.

Lünenborg, M., Linke, C., Konrad, L., Fritsche, K., \& Flecke, S. (2012). Geschlecht und Ethnizität in audiovisuellen Medien. Methodologische und methodische Herausforderungen intersektionaler Medieninhaltsanalyse [Gender and ethnicity in audiovisual media: Methodological and methodical challenges of intersectional media content analysis]. In T. Maier, M. Thiele \& C. Linke (Eds.), Medien, Öffentlichkeit und Geschlecht in Bewegung: Forschungsperspektiven der kommunikations- und medienwissenschaftlichen Geschlechterforschung [Media, publics and gender in motion: Perspectives from communication and media gender studies] (pp. 99-114). Bielefeld: transcript.

Lünenborg, M., \& Maier, T. (2013). Gender Media Studies. Eine Einführung [Gender media studies: An introduction]. Stuttgart: UTB, UVK.

Mayer, V. (2011). Below the line: Producers and production studies in the new television economy. Durham, NC: Duke University Press.

Mikos, L. (2008). Film- und Fernsehanalyse [Film and television analysis]. Konstanz: UVK.

Mulvey, L. (1985). Visual pleasure and narrative cinema. In B. Nichols (Ed.), Movies and methods (pp. 305-315). Berkley: University of California Press.

Pospiech, P. (2018). Qualität kommt von Qual [Quality comes from torture]. Forschung \& Lehre, 4, 285.

Prommer, E., \& Linke, C. (2019). Ausgeblendet. Frauen im deutschen Film und Fernsehen. [Faded out:Women in German film and television]. Köln: Herbert von Halem Verlag.

Prommer, E., Linke, C., \& Stüwe, J. (2017). Is the Future Equal? Geschlechterrepräsentationen im Kinderfernsehen [Gender representations in children's television]. TelevIZIon, 30(2), 4-10. 
Prommer, E., Wegener, C. \& Linke, C. (2019). Geschlechterdarstellungen auf YouTube. Das enge Spektrum der YouTuberin und das weite Feld der Männer [Gender representations on YouTube: The narrow spectrum of the YouTuberin and the wide field of men]. BZgA Forum für Sexualaufklärung und Familienplanung, 1, 16-20.

Prommer, E., \& Schoeller Bouju, B. (2020). Sechster Regie-Diversitätsbericht des Bundesverbandes Regie e.V. (BVR) für das Jahr 2018. Genderanalyse zur Regievergabepraxis in deutschen fiktionalen Primetime-Programmen von ARD, ZDF, RTL, SAT.1, Pro7 und VOX sowie im deutschen Kinospielfilm $\left[6^{\text {th }}\right.$ director diversity report of the Bundesverband Regie e. V. (BVR) for the year 2018: Gender analysis of directing practice in German fictional primetime programs of ARD, ZDF, RTL, SAT.1, Pro7 and VOX as well as in German feature films]. Berlin: BVR.

Scheer, U. (2001). Geschlechterproduktionen in populären Fernsehtexten. Oder: Was kann ein weiblicher Captain? [Gender productions in popular television texts. Or: What can a female captain do?]. In E. Klaus, J. Röser \& U. Wischermann (Eds.), Kommunikationswissenschaft und Gender Studies [Communication science and gender studies] (pp. 103-123). Wiesbaden: Springer VS.

Sink, A., \& Mastro, D. (2017). Depictions of gender on primetime television: A quantitative content analysis. Mass Communication and Society, 20(1), 3-22. https://doi. org/10.1080/15205436.2016.1212243.

Smith, S. L., Choueiti, M., Prescott, A., \& Pieper, K. (2012). Gender roles \& occupations: A look at character attributes and job-related aspirations in film and television. An Executive Report. Geena Davis Institute on Gender in Media. Retrieved from http://seejane.org/wp-content/ uploads/full-study-gender-roles-andoccupations-v2.pdf.
Storsul, T., \& Fagerjord, A. (2010). Digitization and media convergence. In W. Donsbach (Ed.), The international encyclopedia of communication. Hoboken, NJ: John Wiley \& Sons. https:// doi. org/10.1002/9781405186407.wbiecd039.

Wegener, C., Prommer, E., \& Linke, C. (2020). Gender representations on YouTube: The exclusion of female diversity. M/C Journal, 23(6). https://doi.org/10.5204/mcj.2728.

Weiderer, M. (1995). Das Frauen- und Männerbild im deutschen Fernsehen. Eine inhaltsanalytische Untersuchung der Programme von ARD, ZDF und RTL plus [The image of women and men in German television: A content analytical study of the programs of ARD, ZDF and RTL plus] (2 $2^{\text {nd }}$ ed.). Regensburg: Roderer.

Weiß, H.-J., Beier, A., \& Wagner, M. (2015). Konzeption, Methode und Basisdaten der ALM-Studie 2013/2014 [Concept, method and basic data of the ALM study 2013/2014]. In Die Medienanstalten ALM (Ed.), Programmbericht Fernsehen in Deutschland 2014 [Program report television in Germany 2014] (pp. 221-273). Leipzig: Vistas.

West, C., \& Zimmerman, D. H. (1987). Doing gender. Gender and Society, 1(2), 125-151.

Winker, G., \& Degele, N. (2011). Intersectionality as multi-level analysis: Dealing with social inequality. European Journal of Women's Studies, 18(1), 51-66.

Wolf, B. (2008). Geschlechterdarstellung in den Nachrichten: Monitoring in den Nachrichten [Gender representation in the news: Monitoring in the news]. In J. Dorer \& B. Geiger (Eds.), Medien - Politik-Geschlecht. Feministische Befunde zur politischen Kommunikationsforschung [Media-Politics-Gender. Feminist findings from political communication studies] (pp. 66-78). Wiesbaden: VS. 